\title{
The Effect of Employee Engagement on Individual Performance: A Case Study*
}

\author{
Kadir AKTAŞ (iD a Erman KILINÇ iD b Edip DOĞAN (iD c \\ a Ministry of Defense, Logistics Department, Turkey aktas0072@hotmail.com \\ b Niğde Ömer Halisdemir University, Niğde, Turkey ermankilinc@ohu.edu.tr \\ c Adıyaman University, Adıyaman, Turkey edogan@adiyaman.edu.tr
}

\begin{tabular}{|c|c|}
\hline ARTICLE INFO & ABSTRACT \\
\hline $\begin{array}{l}\text { Keywords: } \\
\text { Job Engagement }\end{array}$ & $\begin{array}{l}\text { Purpose - The purpose of this study is to examine the effects of employee engagement (dedication, } \\
\text { absorption, and vigor sub-dimensions) on individual performance. }\end{array}$ \\
\hline $\begin{array}{l}\text { Dedication } \\
\text { Absorption } \\
\text { Individual Performance }\end{array}$ & $\begin{array}{l}\text { Design/methodology/approach - The data have been collected through an online questionnaire } \\
\text { from } 843 \text { employees working in Istanbul, Ankara, and Eskişehir provinces. The results have been } \\
\text { analyzed with SPSS } 21 \text { and AMOS 24. Reliability, normality, explanatory factor analysis, } \\
\text { confirmatory factor analysis, correlation, and structural equation model analyses have been utilized. }\end{array}$ \\
\hline $\begin{array}{l}\text { Received } 22 \text { November } 2020 \\
\text { Revised } 21 \text { February } 2021 \\
\text { Accepted } 5 \text { March } 2021\end{array}$ & $\begin{array}{l}\text { Findings - According to the findings of the study; It has been determined that dedication, } \\
\text { absorption and vigor sub-dimensions adequately represent the job engagement scale. In addition, it } \\
\text { has been determined that job engagement independent variable has had a positive and statistically } \\
\text { significant effect on the individual performance dependent variable. }\end{array}$ \\
\hline $\begin{array}{l}\text { Article Classification: } \\
\text { Research Article }\end{array}$ & $\begin{array}{l}\text { Discussion - In today's competitive conditions, efficiency is essential for every organization. One of } \\
\text { the basic elements that make up efficiency is human capital. This capital is also the most valuable } \\
\text { resource that organizations have. According to the results of the studies, the higher employees' job } \\
\text { engagement level is, the higher their individual performance is. Determining the factors affecting } \\
\text { the level of job engagement positively and negatively and producing policies accordingly will have } \\
\text { a positive effect on individual as well as organizational performance. }\end{array}$ \\
\hline
\end{tabular}

\section{Introduction}

There has been an increasing need for new performance management strategies. However, due to the wideranging impact of globalization today, the management process has become complicated in businesses. While companies are looking for new ways to manage employee performance, several post-modern concepts, such as job engagement, organizational commitment, organizational identification, organizational passion, and organizational resilience, have been studied within the scope of positive organizational behaviors. In addition to focusing on positive behaviors in employees, these concepts also focus on providing a strategic competitive advantage by ensuring that all resources, especially human resources, are used most effectively in today's globally competitive environment. While previous studies focused on the effectiveness of some of these new study fields (Koçel, 2011), job engagement has been a popular field in recent years (Maslach et al., 2001; Shanmuga \& Vijayadurai, 2014; Shukla et al., 2015).

In a study conducted in the USA, $20 \%$ of the employees have been found to have full engagement (Attridge, 2009: 387). In other words, they lead innovations, carry their organizations forward, work patiently, and show a very deep dedication to their organizations. The study also showed that $60 \%$ of the employees have been expressed as the "middle majority" of reasonably dedicated employees, and the remaining $20 \%$ constitute the group of employees who are psychologically distant from work and not devoted. Attridge (2009) stated that the annual cost of this last group to the American economy is around \$250-350 million. The study suggested

*Bu çalışma İnönü Üniversitesi Sosyal Bilimler Enstitüsünde yürütülen Aktaş Kadir (2019) “İşgörenlerin Adanmışlık Düzeyi ve Örgütsel Özdeşleşme İlişkisinin Performans Algısına Etkisini Belirlemeye Yönelik Bir Araştırma” isimli (Yayımlanmamış) Doktora Tezinden üretilmiştir.

\section{Suggested Citation}

Aktaş, K., Kılınç, E., Doğan, E. (2021). The Effect of Employee Engagement on Individual Performance: A Case Study, Journal of Business Research-Turk, 13 (1), 112-122. 
that employing qualified and diligent employees without a dedicated attitude has some potential risks, which constitutes the starting point of this study.

Therefore, in this study, we've examined the concept of "job engagement" and its effects on performance perception. For this purpose, the data obtained from a total of 843 people have been analyzed using various statistical methods. The obtained results have been evaluated by converting them into the related tables. According to the evaluations made as a result of the study; it has been determined that there is a statistically significant relationship between job engagement attitude and individual performance perception. Thus, the levels of the independent variable (job engagement) and its sub-dimensions affecting the dependent variable (performance perception) in the research model have been explained. As a result of these evaluations, the research has reached its final result.

\section{Conceptual Framework}

In the light of the explanations above, an extensive literature study has been conducted on the concepts of job engagement and performance described as post-modern terms. Engagement means "a person's concentrating all his/her efforts and strength on a certain goal". Organizational engagement is that employee adopts the goals of the organization and concentrates all his/her efforts in line with the goals of the organization (Maslach et al., 2001; Shanmuga \& Vijayadurai, 2014; Shukla et al., 2015). It can be said that the highest level of organizational engagement is "organizational fanaticism and sacrifice" (Koçel, 2011: 534).

Job engagement can be defined as positive emotions about work (Kanten, 2012: 8). It can also be defined as "positive and emotional motivation that consists of energy, loyalty (devotion) and adoption" (Aybas, 2014: 8; Bakker et al, 2008: 187). It is also defined as a positive and satisfied mood that consists of the energies, commitment (strong commitment) and internalization of the employee towards her/his job. (Schaufeli et al., 2006: 701). In this context, Schaufeli et al. (2006) examined the engagement attitude to work in three dimensions: dedication, absorption and vigor.

Dedication is expressed in terms such as a person's strong integration with his/her job, his/her strong desire for the work, the meaning and enthusiasm he/she places on the work (Gül \& Erol, 2016: 55). Absorption means that time passes quickly while working and the employee has difficulty in separating himself/herself from the job. In short, it is the situation where the job becomes a hobby for the employee (Aybas, 2014: 16). Vigor is a feature that consists of high level energy, logical flexibility while working, willingness of the employee to work and even steadfastness in the face of difficulties (Schaufeli et al., 2006:702).

Job engagement is important in terms of making the best use of human capacity, knowledge and skills, which are the most important source of competition today, and ensuring organizational efficiency. Because today's competitive conditions require employees to be able to work at full capacity, to perform their jobs with high motivation, and to be mentally and physically dedicated to their jobs (Kanten, 2012: 44). Furthermore, in an economy dominated by service and information sectors, having engaged employees who can show success in a rapidly changing environment will also be a strategic advantage (Castellano, 2016: 99100).

In the dictionary of Turkish Language Association (TDK), the meaning of performance is given as "success" (www.tdk.gov.tr, 19.10.2020). The term performance is an English word in its origin; it has meanings such as doing, performing, and success. Performance is a concept used to express whether a job is achieved in terms of the intended goal qualitatively and quantitatively (Bilgin, 2011: 149). In some studies, the concept of performance perception has been defined as "individual performance based on self-assessment" (Aktaş \& Şimşek, 2014: 31). Performance perception used in this research is the evaluation of the performance that the employee feels. In short, it can be expressed as self-evaluation of the employee, that is, self-evaluation.

Performance is a multidimensional structure that consists of many interrelated factors. Similarly, performance is strongly linked to business results, the organization's strategic goals, customer satisfaction, and economic results (Öztürk, 2006: 12). Literature reviews show that commitment to work is closely linked to organizational performance results. Organizations with engaged employees enjoy high staff attendance, production, profitability, growth rate and customer satisfaction. On the other hand, organizations with employees who aren't engaged suffer from loss of expertise and experience, increased absenteeism rates, lower customer loyalty and less productivity (Markos \& Sridevi, 2010: 94). 


\section{The Methodology}

\subsection{The Universe and Sample}

The universe of the study is Ankara Metropolitan Municipality, Eskişehir Odunpazarı Municipality, Ankara AFAD Headquarters and ASIS Elektronik ve Bilişim A.Ş., consisting of a total of 6182 people. Since it is not possible to reach this number in terms of both time and cost, a random sample has been preferred.

Based on this preference, the answers given by those who see the "eligible" regarding these are presented in ANNEX (A-C). 880 of the approximately 1000 questionnaire forms have returned back, 37 of them have been accepted to be invalid. 555 employees from Ankara Metropolitan Municipality and 92 employees of Odunpazarı Municipality in Eskişehir, 98 employees from AFAD Headquarters in Ankara and ASIS Elektronik ve Bilişim A.Ş. It includes a total of 843 participants, 98 of which are employees. The data obtained are shown in Table.1. Since the ratio $\alpha=0.05$ and $q=0.05$ exceeds the number of 384 calculated for 100 million samples, the universe-sample size is considered to be sufficient in this study.

Table 1. Sample Sizes for $\alpha=0.05$

\begin{tabular}{lccc}
\hline Sample Size & \multicolumn{3}{c}{$\pm \mathbf{0 . 0 5}$ sampling error (d) } \\
\cline { 2 - 4 } & $\mathrm{p}=\mathbf{0 . 5}$ and $\mathbf{q}=\mathbf{0 . 5}$ & $\mathrm{p}=\mathbf{0 . 8}$ and $\mathbf{q}=\mathbf{0 . 2}$ & $\mathbf{p = 0 . 3}$ and $\mathbf{q}=\mathbf{0 . 7}$ \\
\hline 100 & 80 & 71 & 77 \\
500 & 217 & 165 & 196 \\
750 & 254 & 185 & 226 \\
1000 & 278 & 198 & 244 \\
2500 & 333 & 224 & 286 \\
10000 & 370 & 240 & 313 \\
100000 & 383 & 245 & 322 \\
1000000 & 384 & 246 & 323 \\
100 millions & 384 & 245 & 323 \\
\hline
\end{tabular}

Reference: Yazıcıŏ̆lu \& Erdoğan (2004: 50; from Yirik, Ş. et al., 2016: 10).

\subsection{Assumptions of the Study}

Assumptions for the study are listed below:

- Participants have the ability to represent the main mass,

- The participants have answered the questionnaire sincerely,

- In order to reach the research results, the most appropriate statistical methods have been chosen

- The measurement programs used in the research are valid and reliable.

\subsection{The Limitations of the Study}

The Limitations of the study are listed below:

- The research is limited in terms of subject and application and has certain limitations in terms of time, cost and opportunities.

- The scope of the research in terms of its subject is that it constitutes a study to determine the effects of employees' engagement to work and organizational identification on performance perceptions. 
- In terms of implementation, the research includes municipal employees in Ankara and Eskişehir, employees in AFAD Headquarters in Ankara and employees in ASIS Elektronik ve Bilişim A.Ş.

- There is no aim such as generalizing the results of the study.

- This reflects the evaluation of the data obtained by the researchers as a result of the study and does not reflect the views of the institutions that allow surveys.

\subsection{The Method and Findings}

This section includes the data collection method used in the study, the hypotheses of the research, demographic variables, reliability and normality analyses, factor analysis and path analysis.

In the study, questionnaire forms have been used as data collection tool. The institutions to which the questionnaires have been applied are randomly selected. So the questionnaires have been obtained according to the simple random sampling method. The data obtained from the questionnaires have been processed with SPSS 21 and AMOS 24 package programs.

Within the scope of the survey, 52 of the institutions operating in Ankara and surrounding provinces have been reached through written letters, electronic letters or face-to-face interviews, and a total of 1,000 questionnaires have been distributed. 880 of the distributed questionnaires have returned back and 37 of them have been eliminated either because they've contained incomplete and incorrect data or because they have had extreme values. The remaining 843 questionnaires have been evaluated to represent the population according to Table 1.

The survey method, one of the first-hand data collection methods, has been used in the research. The survey form of the research consists of 3 sections and 34 questions. It consists of a total of 34 questions, namely demographic information ( 7 questions) in the first section, questions of job engagement in the second section (13 questions), and employee performance perception scale questions (14 Questions) in the third section.

The first part consists of questions to determine the demographic characteristics of the employees participating in the study. In the second part, the job engagement scale consisting of 13 questions developed by Schaufeli et al. (2006) has been used.

For the "job engagement" scale, which is considered as the first variable, 3 items have been excluded from the analysis because they've had a high factor load in more than one dimension. The sub-factors of the scale are divided into 3 as they are in the original scale. These factors are determined as "dedication, absorption and vigor" respectively. Although a 7-point Likert-type answer option is offered in the original of the UWES scale, it has been observed that the 5-point and 6-point Likert application have also been used in different studies. In this study, 7-point Likert has been applied [Very Rare (several times a year or less): 1, Rare (once a month or less): 2, Sometimes (several times a month): 3, No Idea: 4, Often (Once a week): 5, Generally (Several times a week): 6, Always (Every day): 7]. The lowest score that can occur here is 13, and the highest score is 91. In the third part, a scale consisting of 14 questions taken from two different studies has been used to measure the perception of the employees' individual performance. The first 4 survey questions that make up the performance questionnaire were developed by Kirkman and Rosen (1999) and Sigler and Pearson (2000). These questions were translated from English to Turkish by a person who is proficient in the subject and the languages, and used by Çöl (2008) to eliminate potential errors that may arise. Translations of expressions from English to Turkish have been used. The next 3 questions (5-7) that make up the performance questionnaire were developed by Fuentes et al. (2004) and Rahman and Bullock (2005. Three items of this scale, which was adapted to Turkish by Göktaş (2004), were used after validity and reliability analyses (Cronbach alpha reliability coefficient 0.91 ) had been made (Göktaş, 2004: 93). The last 7 questions (8-14) have been prepared in line with the expert opinion and added to the performance scale in order to determine the perception of performance of the employee. Since it is determined in the national literature that most researchers apply 5-point Likert, it is applied in this study accordingly.

Hypotheses to explain the effects of employees' engagement to work on the perception of individual performance based on the sub-dimensions of the variables are presented below.

The hypotheses created for the purpose of this study are as follows:

- $\mathrm{H}_{1}$ : Job engagement scale has a positive and significant effect on individual performance 
- $\mathrm{H}_{2}$ : There is a positive and significant relationship between dedication dimension and individual performance

- $\mathrm{H}_{3}$ : There is a positive and significant relationship between absorption dimension and individual performance

- $\mathrm{H}_{4}$ : There is a positive and significant relationship between vigor dimension and individual performance.

The model established according to the hypotheses of the study is shown in Figure 1.

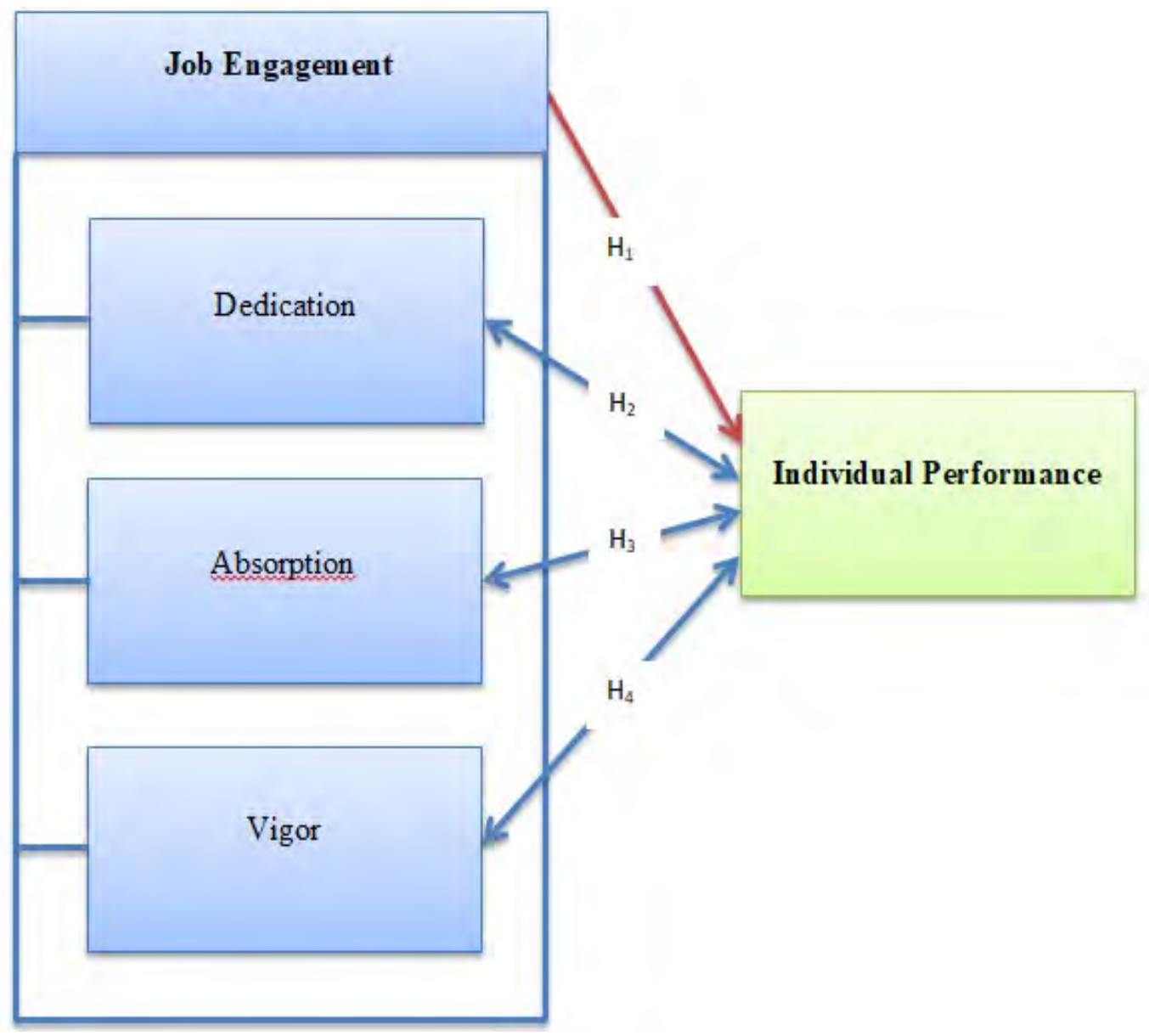

Figure 1. The Model and Hypotheses of the Study on Investigating the Effects of Employees' Commitment Level on Individual Performance

Information on the demographic variables of the participants, including gender, age, marital status, education level, working time in the current institution, task and total working time, are shown in Table 2.

Table 2. Demographic Variables

\begin{tabular}{lcc}
\hline Gender & Number & Percentage \\
\hline Female & 253 & 30 \\
Male & 590 & 70 \\
Total & 843 & 100,0 \\
\hline Age & Number & Percentage \\
\hline $18-25$ & 123 & 14,6 \\
$26-35$ & 330 & 39,1 \\
$36-45$ & 241 & 28,6 \\
\hline
\end{tabular}




\begin{tabular}{lcc}
\hline $46-55$ & 112 & 13,3 \\
56 and over & 37 & 4,4 \\
Total & 843 & 100,0 \\
\hline Marital Status & Number & Percentage \\
\hline Single & 283 & 33,6 \\
Married & 560 & 66,4 \\
Total & 843 & 100,0 \\
\hline Education & Number & Percentage \\
\hline Primary & 140 & 16,6 \\
Secondary & 262 & 31,1 \\
Undergradute & 376 & 44,6 \\
Graduate & 65 & 7,7 \\
Total & 843 & 100,0 \\
\hline
\end{tabular}

According to the data in Table 2, among 843 people whose survey forms have been evaluated; 253 (30\%) are women and $590(70 \%)$ are men. The age ranges of the participants are as follows; $123(14.6 \%)$ are between $18-$ 25, $330(39.1 \%)$ are between $26-35,241(28.6 \%)$ are between $36-45,11246-55(13.3 \%)$ are between and $37(4.4 \%)$ are 56 and above. The marital status of the participants is as follows; $283(33.6 \%)$ are single and $560(66.4 \%)$ are married. The educational status of the participants is as follows; $140(16.6 \%)$ have primary education, 262 $(31.1 \%)$ have high school, $376(44.6 \%)$ have undergraduate and $65(\% 7,7)$ have graduate levels.

In calculating the reliability of the data, Cronbach Alpha coefficient has been taken as basis and values over 0.70 have been accepted as reliable. The reliability values of the scales and dimensions are shown in Table 3 .

Table 3. Reliability Values of the Factors in the Questionnaire

\begin{tabular}{lcc}
\hline Title & Item Number & Cronbach's Alpha \\
\hline Dedication & 5 &, 925 \\
Absorption & 3 &, 839 \\
Vigor & 2 &, 840 \\
Job Engagement & $\mathbf{1 0}$ &, 940 \\
Performance & $\mathbf{1 4}$ &, 924 \\
\hline
\end{tabular}

*All values are significant at $\mathrm{p}<0.001$ level..

According to the information in Table 3, the job engagement scale has 0.940 , the performance scale has 0.924 , dedication size has 0.925 , absorption dimension has 0.839 , and vigor dimension has 0.840 reliability values.

The determination of method to be used in the analysis of the data is very important. The distribution of data must be normal for the use of parametric analysis methods. There are different ways to test the normality of the distribution. One of them is to examine the kurtosis and distortion values of the data. According to Trochim and Donnelly (2001), if the values in a question are within the limit of \pm 2 , the distribution of the data is normal. In this study, the condition has been met.

Exploratory factor analysis is used to explain the items in the scale, to decrease the number of variables by grouping them and to determine the sub-dimensions. To see the power of this analysis, the results of Kaiser- 
Meyer-Olkin (KMO) and Bartlett Sphericity Test are examined. Values above 0.70 for KMO indicate that factors have good explanation power. Exploratory factor analysis results are shown in Table 4.

Table 4. Exploratory Factor Analysis Table

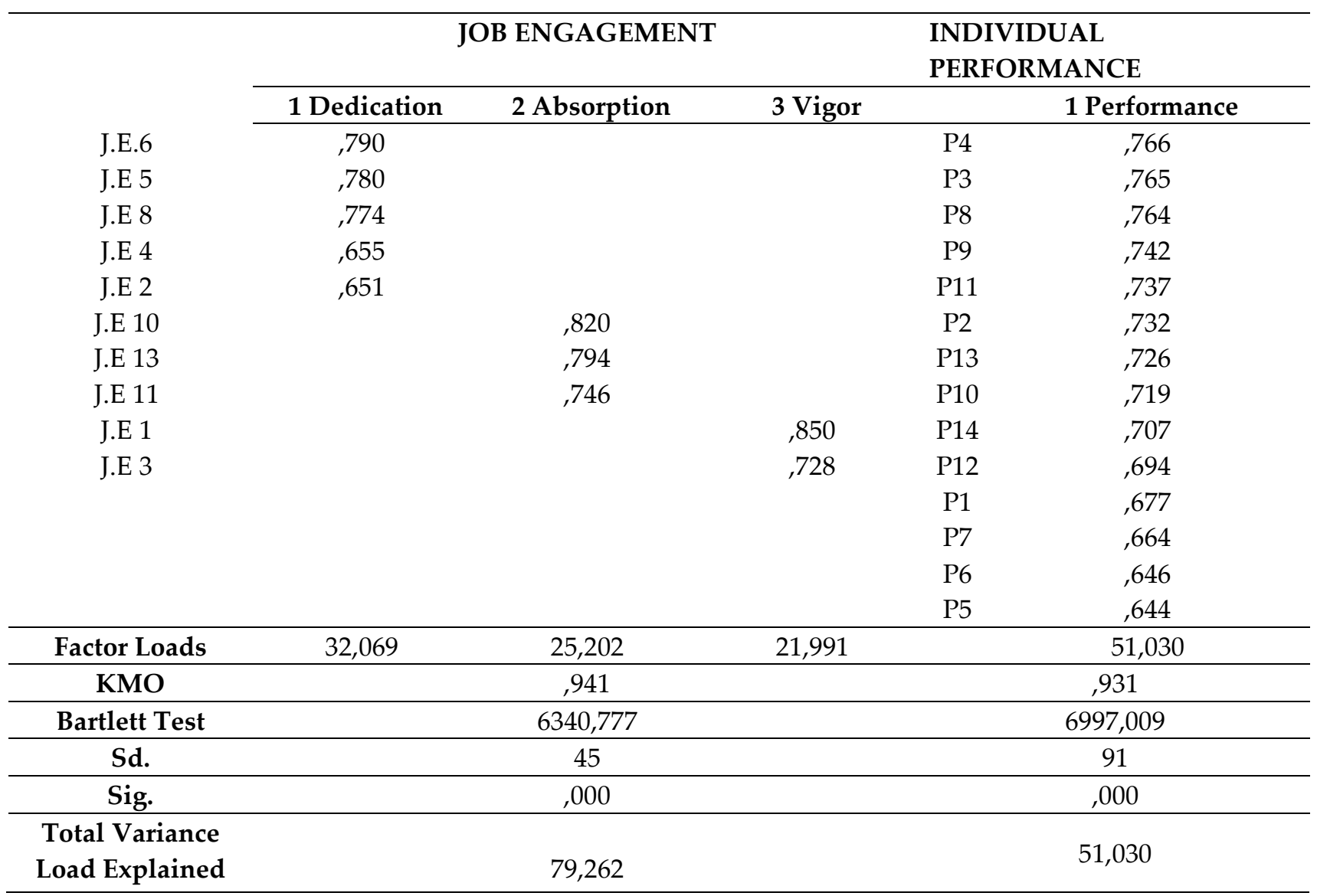

*J.E.: Job Engagement

According to the data in Table 4, the KMO value of the job engagement scale is 0.941 and the Bartlett test value is significant $\left(X^{2}=6340,777 ; \mathrm{p}<0.001\right)$; the $\mathrm{KMO}$ value of the individual performance scale has been found to be 0.931 and the Bartlett test value is significant $\left(X^{2}=6997.009 ; \mathrm{p}<0.001\right)$. In the exploratory factor analysis, expressions that are below 0.40 and / or have binary characteristics have been eliminated. As a result, the job engagement scale has been found to be three-dimensional and the performance scale to be one-dimensional. Accordingly, the dedication dimension consists of 5 expressions, the absorption dimension consists of 3 expressions and the vigor dimension consists of 2 expressions.

After the exploratory factor analysis, it is necessary to look at the correlation values of independent and dependent variables. The data in Table 5 includes the correlation values, means and standard deviations between the variables

Table 5. Correlation Table

\begin{tabular}{lllcc}
\hline & \multicolumn{1}{c}{ Vigor } & Dedication & Absorption & Performance \\
\hline Vigor & 1 & & & \\
Dedication & 0,789 & 1 & & \\
Absorption & 0,633 & 0,707 & 1 & 1 \\
Performance & 0,478 & 0,558 & 0,528 & $\mathbf{5 , 6 5 ^ { * * }}$ \\
Average & $\mathbf{4 , 8 8}$ & $\mathbf{5 , 1 0}$ & $\mathbf{5 , 3 0}$ & $\mathbf{1 , 0 4}$ \\
Std Dev. & $\mathbf{1 , 7 5}$ & $\mathbf{1 , 6 3}$ & $\mathbf{1 , 4 8}$ & \\
\hline
\end{tabular}

*All correlation values in the table are significant at $\mathrm{p}<0.01$ level.

**The scores of the performance scale were calculated according to the 7-point Likert. 
According to the data in Table 5, the correlations between the variables are between 0.478 and 0.789. All correlations are significant at $p<0.01$ level. The standard deviations of the variables are between $1.04-1.75$. In the original scale, the 5-point Likert type scale has been converted into 7-point Likert numerical values in order to provide uniformity in practice.

Confirmatory factor analysis has been performed on the data to test the sub-dimensions determined as a result of the exploratory factor analysis. Confirmatory factor analysis is used to verify a predetermined structure as a model. In this study, the structural equation model established for confirmatory factor analysis has been implemented through the AMOS 24 program.

The structural equation model has some goodness of fit values. These values are used to measure how well the model created fits the sample model. Goodness of fit values is very diverse and there are different opinions about which ones to be used. The fit values and acceptable fit ranges obtained from the confirmatory factor analysis are shown in Table 6.

Table 6. Goodness of Fit Values

\begin{tabular}{lccc}
\hline Index & Good Fit & Acceptable Fit & Values \\
\hline CMIN/DF & $\chi^{2} \leq 3$ & $3 \leq \chi^{2} \leq 5$ & 3,81 \\
CFI & $0,95 \leq \mathrm{CFI} \leq 1,00$ & $0,90 \leq \mathrm{CFI} \leq 0,97$ &, 99 \\
NFI & $0,95 \leq \mathrm{NFI} \leq 1,00$ & $0,90 \leq \mathrm{NFI} \leq 0,95$ &, 98 \\
GFI & $0,95 \leq \mathrm{GFI} \leq 1,00$ & $0,85 \leq \mathrm{GFI} \leq 0,90$ &, 92 \\
SRMR & SRMR $\leq 0,05$ & $0,05 \leq \mathrm{SRMR} \leq 0,08$ &, 023 \\
RMSEA & RMSEA $\leq 0,05$ & $0,05 \leq \mathrm{RMSEA} \leq 0,10$ &, 074 \\
\hline
\end{tabular}

Reference: Schermelleh-Engel et al., 2003: 43

When the data in Table 6 are analyzed it is observed that all values, except the chi-square (CMIN/DF), goodness of fit are within the acceptable range.

After the necessary corrections have been made after exploratory factor analysis and confirmatory factor analysis, path analysis has been utilized. Path analysis is shown in Figure 2.

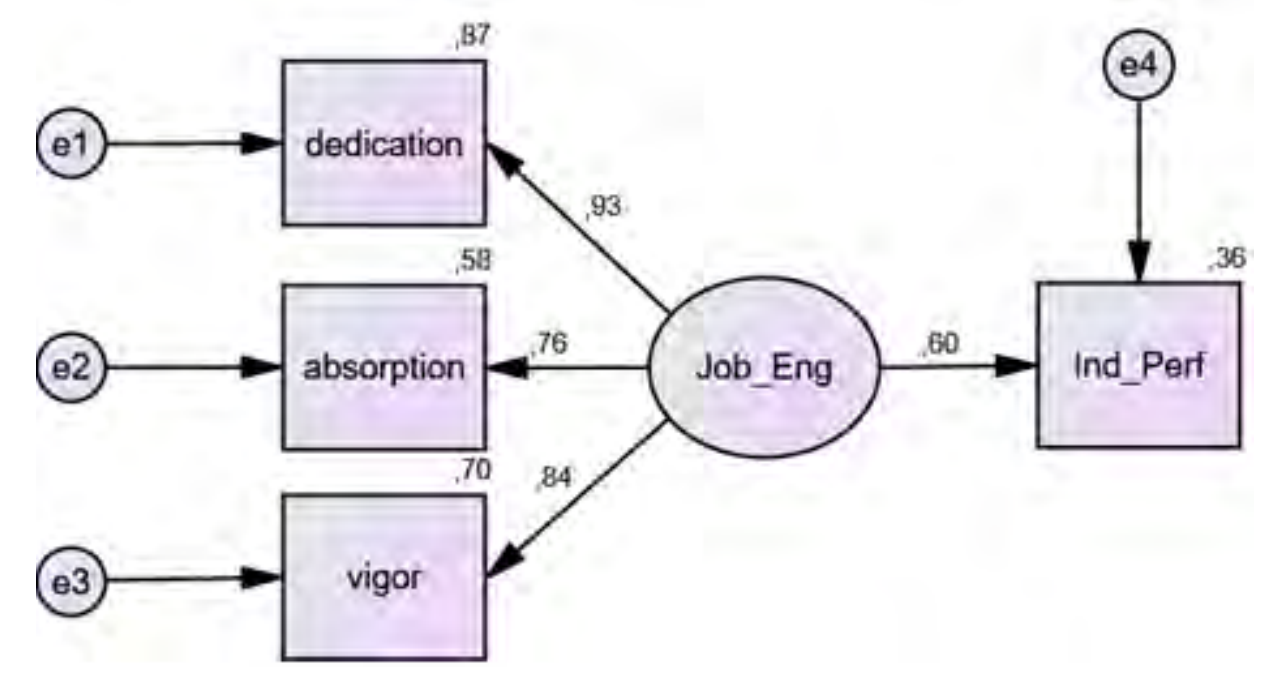

Figure 2. Path Analysis

According to the data in Figure 2;

- Vigor sub-dimension affects the job engagement scale positively and strongly $(\beta=0.84)$, 
- There is a positive and strong relationship between engagement scale and dedication sub-dimension $(\beta=$ $0.93)$,

- Absorption has a positive and strong effect on the engagement scale with its subscale $(\beta=0.76)$,

- The job engagement scale has a positive and strong effect on individual performance $(\beta=0.60)$.

Furthermore, the variance $\left(\mathrm{R}^{2}\right)$ value of the model has been measured as 0.36 . In other words, the rate of the model which is established to represent the real universe is $36 \%$. All regression weights of the model are significant at the level of $\mathrm{p}<0.01$.

According to the findings, the hypotheses of the research have been accepted or rejected. Table 7 shows the acceptance / rejection status of the hypotheses.

Table 7. Acceptance/Rejection Status of Hypotheses

\begin{tabular}{lccc}
\hline Hypothesis No & Hypothesis & $\mathbf{P}$ & Acceptance/Rejection \\
& Values & \\
\hline
\end{tabular}

$\mathrm{H}_{1}$

$\mathrm{H}_{2}$

$\mathrm{H}_{3}$

$\mathrm{H}_{4}$
The job engagement scale has a positive and significant impact on the individual performance scale.

$\mathrm{p}<0,01$

Accepted

There is a positive and significant relationship between dedication dimension and individual performance

$\mathrm{p}<0,01$

Accepted

There is a positive and significant relationship between absorption dimension and individual performance

$\mathrm{p}<0,01$

Accepted

There is a positive and significant relationship between vigor dimension and individual performance. $\mathrm{p}<0,01$

Accepted

According to Table 7, all four hypotheses of the study have been accepted as they are significant at $\mathrm{p}<0.01$ level.

\section{Conclusion and Suggestions}

It can be concluded from the result of the study that there is a significant relationship between "job engagement" and "employee perception of performance". This result is evaluated to be compatible with some research results. For example, according to the Job Requirements-Resources-JD-R model developed by Bakker and Demerouti (2008); engagement to work has a positive effect on job performance. According to JD-R model; devoted and well performing employees enter a self-motivated devotional spiral over time (Bakker and Demerouti, 2008: 218-219). Also, there is a positive and significant relationship between the "dedication" subdimension and the "employee performance perception". This hypothesis result is found to be compatible with the results of some previous research (Bakker et al., 2008: 557-560).

However there is no positive and significant relationship between the "vigor at work" sub-dimension and the "employee perception of performance". Although the analysis result in this study does not support this hypothesis, it has been stated that the dimension of vigor has affected the performance in a similar study conducted by Bakker et al. (Bakker et al., 2008: 562). Besides, It has been observed that there is a positive and significant relationship between "being involved with the job" and "employee performance". In a similar 
study, it was found by Brown and Leigh (1996: 364) that absorption had a positive relationship with performance.

According to the results of the study, it is suggested that researchers who will conduct studies on subjects such as engagement and commitment should pay attention to the terms in the sources that the authors refer to in order to avoid the confusion of the concept. Besides, the questionnaire in this study consists of 34 questions. For this reason, volunteer participants want to complete the questionnaire as soon as possible. Therefore, it has been determined that the participants generally preferred the same options without reading the questionnaire questions completely. To prevent this situation, researchers are recommended to simplify the survey questions and to reduce their number. Furthermore, surveys and research should be conducted on issues that will enable employees to perceive their jobs as their most important value, and general priorities should be determined in this regard. By this way it will be possible for organizations to create an army of dedicated employees.

Moreover, it is understood from the research that only $20 \%$ of the employees are actively dedicated to their job, about $20 \%$ are not dedicated and the remaining $60 \%$ are neutral. In this context, it should be ensured that the $20 \%$ of the actively dedicated people are identified and honored in a way to set a precedent and ensure their continuing work. In addition to this, the determination of the problem areas of $20 \%$ who aren't dedicated and the improvement of the problem areas should be addressed in terms of performance and employee turnover rate and organizations should try to ensure the dedication of the approximately $60 \%$ of the neutral group. Finally, concepts such as comprehending the meaning of the business, autonomy, the possibility of ascending, seeing the result as a whole and belonging should be implemented by the management with appropriate methods.

\section{References}

Aktaş, H. \& Şimşek, E. (2014). Örgütsel sessizlik ile algılanan bireysel performans, örgüt kültürü ve demografik değişkenler arasındaki etkileşim. Akdeniz Üniversitesi İktisadi ve İdari Bilimler Fakültesi Dergisi, 14(28), 24-52.

Attridge, M. (2009). Measuring and managing employee work engagement: A review of the research and business literature, Journal of Workplace Behavioral Health, 24(4), 383-398.

Aybas, M. (2014). İnsan kaynakları uygulamalarının çalışanların işe adanmışlı̆̆ı üzerindeki etkisi ve pozitif psikolojik sermayenin aracı rolü konuya ilişsin bir araştırma (Yayınlanmış Doktora Tezi), İstanbul Üniversitesi Sosyal Bilimler Enstitüsü, İstanbul.

Bakker, A. B. \& Demerouti, E. (2008). Towards a model of work engagement. Career Development International, 13(3), 209-223.

Bakker, A. B., Schaufeli, W. B., Leiter, M. P. \& Taris, T. W. (2008). Work engagement: An emerging concept in occupational health psychology. Work and Stress, 22(3), p.187-200.

Bilgin, L. (2011). İnsan Kaynakları Yönetimi (Ed. Ramazan Geylan). Eskişehir: Anadolu Üniversitesi Yayınları.

Brown, S. P. \& Leigh, T. W. (1996). A new look at psychological climate and its relationship to job involvement, effort, and performance. Journal of Applied Psychology, 81(4), 358-368.

Castellano, W.G. (2016). 21. Yüzyıl İşgücü Adanmışlı̆̆ı İ̧in Uygulamalar (Çev.Özlem Kunday). Ankara: Nobel Akademik Yayıncilik.

Çöl, G. (2008). Algılanan Güçlendirmenin İş gören Performansı Üzerine Etkileri. Doğuş Üniversitesi Dergisi, 9(1), 35-46

Gül, H. \& M.Erol, (2016). Muhasebe meslek mensuplarında işe bağlllık ve çalışma ahlâkının mesleki etik davranışına etkisi, Mali Çözüm, 137, 51-74.

Fuentes-Fuentes, M., Albacete-Saez, A. \& Llorens-Montes, J., (2004). The Impact of Environmental Characteristics on TQM Principles and Organisational performance, International Journal of Management Science Omeg, 32(6), 425-442 
Göktaş, K, (2004). Toplam Kalite Yönetimi İlkeleri Uygulamalarının İşletme Performansı Üzerine Etkileri, (Yayımlanmamış Yüksek Lisans Tezi), Kadir Has Üniversitesi Sosyal Bilimler Enstitüsü, İstanbul.

İşgücü İstatistikleri, http://www.tuik.gov.tr.pdf (Erişim tarihi: 19 Kasım 2018).

Kanten, P. (2012). İşgörenlerde işe adanmanın ve proaktif davranışların oluşumunda örgütsel güven ile örgütsel özdeşleşmenin rolü, (Yayınlanmış Doktora Tezi), Süleyman Demirel Üniversitesi Sosyal Bilimler Enstitüsü, Isparta.

Kirkman, B. L. \& Rosen, B. (1999). Beyond self-management: Antecedents and consequences of team empowerment. Academy of Management Journal, 42: 58-74.

Koçel, T. (2011). İşletme yöneticiliği, İstanbul: Beta Yayıncilık.

Markos, S. \& Sridevi, M.S. (2010). Employee Engagement: The Key to Improving Performance, Published by Canadian Center of Science and Education, International Journal of Business and Management, 5(12), 8996.

Maslach, C., Schaufelli, W. B. \& Leiter, M. P. (2001). Job burnout. Annual Review of Psychology, 52, 397-422.

Öztürk, Ü. (2006). Organizasyonlarda Performans Yönetimi, İstanbul: Sistem Yayıncılık.

Rahman, S. \& Bullock, P. (2005). Soft TQM, hard TQM, and organizational performance relationships: An empirical investigation, Omega, 33(1), 73-83.

Schaufeli, W. B., Bakker, A. B., \& Salanova, M. (2006). The measurement of work engagement with a short questionnaire: A cross-national study. Educational and Psychological Measurement, 66(4), 701-716.

Schermelleh-Engel, K., Moosbrugger, H., \& Müller, H., (2003). Evaluating the fit of structural equation models: tests of significance and descriptive goodness-of-fit measures. Methods of Psychological Research Online, 8(2), 23-74.

Shanmuga, P. \& Vijayadurai, J. (2014). Employee Engagement in Organisations. European Journal of Business and Management, 6(34), 5-10.

Shukla, S., Adhikari, B. \& Singh, V. (2015). Employee engagement-role of demographic variables and personality factors, Amity Global HRM Review, 5, 65-73.

Sigler, T.H. \& Pearson, C.M. (2000). Creating an empowering culture: Examining the relationship between organizational culture and perceptions of empowerment. Journal of Quality Management, 5(1), 27-52.

Trochim, W. M. \& Donnelly, J. P. (2001). Research methods knowledge base, Cincinnati: Atomic Dog Publishing.

Türk Dil Kurumu, http://www.tdk.gov.tr (Erişim Tarihi: 7 Ekim 2019)

Türkiye'de Mesleki Görünüm, https://media.iskur.gov.tr/13497/turkiyede-mesleki-gorunum.pdf, (Erişim Tarihi: 17 Ocak 2018)

Yazıcıoğlu, Y. \& Erdoğan, S. (2004). SPSS uygulamalı bilimsel araştırma yöntemleri. Ankara: Detay Yayıncılık

Yirik, S.., Uslu, A., Sancar, M. F. \& Kutukız, D. (2016). Otel işletmelerinde örgütsel sessizlik ve örgütsel adalet ilişkisi: Antalya örneği. Yenifikir Dergisi, 16, 7-15. 